\title{
GHRH Gene
}

National Cancer Institute

\section{Source}

National Cancer Institute. GHRH Gene. NCI Thesaurus. Code C38320.

This gene is involved in the stimulation of growth hormone release. 